\title{
Influence of temperature on dietary metal uptake in Arctic and temperate mussels
}

\author{
Stephen B. Baines*, Nicholas S. Fisher, Erin L. Kinney \\ Marine Sciences Research Center, Stony Brook University, Stony Brook, New York 11794-5000, USA
}

\begin{abstract}
Assessments of the potential for metal and radionuclide contamination of arctic organisms have been based in part on experiments on organisms collected from temperate zones, even though adaptation to Arctic environments may enhance bioaccumulation of contaminants. Here, we compare the potential for blue mussels Mytilus edulis originating from the Arctic and from temperate zones to accumulate trace metals from filtered algal food at 2 temperatures. Geographic origin had little effect on either the percentage of metal assimilated from food (the assimilation efficiency, AE) or the rate at which ingested metal was excreted (measured by the efflux constant, $k_{\mathrm{e}}$ ). By comparison, experimental temperature had much larger effects, causing AE for Ag, Am and $\mathrm{Zn}$ to be 122 to $945 \%$ higher, and $k_{\mathrm{e}}$ for $\mathrm{Cd}$ and Co to be 50 to $80 \%$ lower at $2^{\circ} \mathrm{C}$ than at $12^{\circ} \mathrm{C}$. The effect of temperature on the trophic accumulation factor $\left(\mathrm{TAF}=\mathrm{AE} / \mathrm{k}_{\mathrm{e}}\right)$ was even more pronounced and systematic, with all metals characterized by larger TAFs at $2^{\circ} \mathrm{C}$ than at $12^{\circ} \mathrm{C}$. The effects on the TAF were largest for the non-essential metals Ag and Am (6 to 7-fold), smallest for the required elements Co, Se and $\mathrm{Zn}$ (2 to 3-fold) and intermediate for Cd (4-fold). Geographic origin affected the TAF for Cd only, with temperate mussels displaying slightly higher potential for biomagnification. Our study suggests that, with the exception of $\mathrm{Cd}$, mussels from temperate and Arctic zones accumulate metals from food similarly, and that temperature has a much larger impact on accumulation than population origin.
\end{abstract}

KEY WORDS: Metals • Dietary uptake • Bioaccumulation · Temperature • Arctic • Mytilus • Assimilation efficiency · Efflux constant

Resale or republication not permitted without written consent of the publisher

\section{INTRODUCTION}

Accumulation of trace metals and radionuclides by Arctic organisms has been of increasing concern over the last 2 decades. Concentrations of common contaminant metals such as $\mathrm{Pb}, \mathrm{Cd}, \mathrm{Zn}$ and $\mathrm{Hg}$ are elevated in Arctic marine waters, sediments and organisms near mining areas and certain Russian estuaries (Dietz et al. 1998). Long range atmospheric supply of anthropogenic $\mathrm{Pb}, \mathrm{Hg}$ and other contaminants to Arctic regions from mid-latitudes also occurs (Slemr \& Langer 1992). Long-lived radionuclides of $\mathrm{Pu}$ and $\mathrm{Cs}$ are also present due to past nuclear testing and dumping, river runoff draining contaminated regions, continuing leakage from old disposal sites, and advection from active sources in western Europe (Strand 1998). Contaminant concentrations (for example, $\mathrm{Cd}, \mathrm{Hg}$ and $\mathrm{Se}$ ) may be elevated in the tissues of diverse marine organ- isms in polar waters, including some large Arctic consumer organisms (Dietz et al. 1998, Strand 1998). This pattern exists even though Arctic food chains are shorter than temperate ones and therefore theoretically less prone to biomagnification. These bioaccumulated contaminants may pose risks to both resident marine organisms and human consumers, particularly those populations that rely heavily upon marine organisms for their sustenance (Templeton et al. 1997, Hansen 1998).

While many of the explanations for relatively high contamination in some Arctic organisms invoke supply of contaminants via the atmosphere, rivers, or oceanic currents, the physiological and evolutionary response of organisms to their Arctic environment may also play a role. For example, ambient temperatures may affect accumulation of metals from the environment by affecting feeding rates or metabolic processes (Bayne 
\& Newell 1983, Jørgensen 1990) which may be linked to the bioaccumulation of metals. Such effects have been observed for a wide array of organisms, although these effects appear to be variable (Hutchins et al. 1996a,b, 1998, Boisson et al. 1997). In addition, the adaptations that Arctic organisms must employ to survive in cold environments characterized by a variable supply of food may also affect their tendency to bioaccumulate metals from food.

Much of the body burden of many contaminants in consumer organisms, including $\mathrm{Zn}, \mathrm{Cd}$, Co and Se, can be derived from food (Wang \& Fisher 1999). Metal obtained this way is often distributed in soft tissues of the consumer, and is thus more available for transfer to other consumers, although metal detoxification mechanisms may influence the trophic transfer of metal under some circumstances (Wallace \& Lopez 1996). While high fat concentrations in Arctic prey organisms and their predators, presumably a response to cold temperature and the episodic nature of food supply, can lead to the efficient uptake, trophic transfer and retention of PCBs in Arctic consumers (de March et al. 1998), the trophic transfer of metal is probably not influenced by this factor. However, other adaptations to life at low temperatures that affect intake of metals from food, such as the ability of bivalves in the Arctic to filter effectively or assimilate food more efficiently at low temperatures, may combine with persistent temperature constraints on processes affecting loss of metals, such as respiration and excretion, to increase the potential for bioconcentration of metals from food.

Assessments of potential risk of dietary metal or radionuclide contamination for circumpolar human populations have often generalized from studies that used organisms collected from temperate environments. Consistent differences in the ability of organisms adapted to Arctic and temperate climes to bioconcentrate metal or radionuclide contaminants could call into question the results of such assessments. Some information on bioconcentration factors for a range of contaminants for both Arctic and temperate organisms suggests that significant differences can exist (Fisher et al. 1999). Therefore, it is important to test the effect that such adaptation can play in the accumulation of metals from food.

In this paper, we assess the effect of both temperature and geographic origin on the ability of the common blue mussel, Mytilus edulis, to take up and retain a range of metals from ingested food. $M$. edulis is a cosmopolitan organism that is widely used as a bioindicator of coastal contamination (Phillips 1980), and as a food source for indigenous human populations in the Arctic and elsewhere. The metals we have chosen are representative of contaminant metals and metalloids ( $\mathrm{Zn}, \mathrm{Cd}, \mathrm{Se}, \mathrm{Ag})$ or radionuclides $\left({ }^{241} \mathrm{Am},{ }^{65} \mathrm{Zn}\right.$,
${ }^{57} \mathrm{Co}$ for ${ }^{60} \mathrm{Co}$ ). They also range in behavior, including a particle-reactive but biologically inert Class A metal (Am), a biologically required and potentially toxic borderline metal (Zn), a Class B metal with significant toxicity and a possible biological requirement $(\mathrm{Cd})$, a Class B metal with no known biological function but significant toxicity (Ag), and a required and potentially toxic metalloid that substitutes for covalently bound $\mathrm{S}$ in amino acids and proteins (Se) (Nieboer \& Richardson 1980). Experiments evaluating the behavior of these elements employed radioisotopes in pulse-chase experiments to determine the assimilation efficiency ( $A E$, the fraction of ingested metal assimilated into the tissues of mussels) and the first order efflux constant $\left(k_{\mathrm{e}}\right)$ describing the loss of metal from the mussels (Fisher et al. 1996). Specifically, we examine how these parameters vary systematically for each metal as a function of temperature and geographic origin of the population.

\section{MATERIALS AND METHODS}

Handling of experimental organisms. Mussels Mytilus edulis from the Arctic were collected (courtesy of Dr. Lars Føyn) from the north coast of Norway during the first week of October $2000\left(69^{\circ} \mathrm{N}, 38^{\circ} \mathrm{S}\right.$, water temperature about $6^{\circ} \mathrm{C}$ ) and transported to Tromsø, Norway. Molecular studies have shown that $M$. edulis is the only member of the genus Mytilus in this region (Riginos et al. 2002). The mussels were then sealed in 21 double plastic bags half-filled with ambient seawater, placed in a thick styrofoam container filled with ice, and shipped to Stony Brook, New York. Total transit time from northern Norway to New York was $<2 \mathrm{~d}$. No mussel mortality occurred during transit. Mussels representative of temperate systems were collected several times from Long Island Sound near Old Field, New York. This site is located on Long Island Sound about $75 \mathrm{~km}$ from the mouth of the East River in New York City and is relatively unimpacted by metal contamination. All mussels were kept in $0.2 \mu \mathrm{m}$ filtered Atlantic surface seawater collected $10 \mathrm{~km}$ south of Southampton, NY (SHSW), and fed the coastal diatom Thalassiosira pseudonana. Arctic mussels were maintained at 2 to $8^{\circ} \mathrm{C}$ and temperate mussels at 10 to $14^{\circ} \mathrm{C}$ until the beginning of the experiments.

Culturing and preparation of algal food. The protocols for handling organisms and the experimental design were based on earlier work in our laboratory (Wang \& Fisher 1996). Thalassiosira pseudonana was used as food in these experiments; diatoms are a common component of the plankton assemblages in different regions, including temperate and polar waters, that serve as a food source for Mytilus edulis. For algae 
used to maintain the mussels, SHSW was sterilefiltered through a $0.2 \mu \mathrm{m}$ Millipak filter into sterilized glass flasks and then amended with $f / 2$ levels of nutrients (Guillard \& Ryther 1962). After inoculation, the cultures were grown at $16^{\circ} \mathrm{C}$ with $120 \mu \mathrm{mol}$ photons $\mathrm{m}^{-2} \mathrm{~s}^{-1}$ and a 14:10 h light:dark cycle until they reached late log-phase (cell concentration 5.5 to $10 \times 10^{5}$ cells $\mathrm{ml}^{-1}$ ). To feed the mussels, this culture suspension was dripped directly into aerated buckets containing the mussels. For algae used during the experiments, a lowmetal medium was used (f/2-LM) from which $\mathrm{Cu}, \mathrm{Zn}$ and EDTA were omitted and only $f / 20$ levels of other metals added. Cultures were grown to late log-phase and cells were resuspended off polycarbonate membranes into $250 \mathrm{ml}$ of new sterile-filtered SHSW in a sterilized 11 flask yielding a final concentration of $6.6 \times$ $10^{6}$ cells $\mathrm{ml}^{-1}$.

For algae used during the radiotracer pulse phase, $125 \mathrm{ml}$ of SHSW was amended with f/2-LM, sterilefiltered, followed by microliter quantities of dilute acid containing the gamma-emitting radioisotopes ${ }^{110 \mathrm{~m}} \mathrm{Ag}$, ${ }^{241} \mathrm{Am},{ }^{109} \mathrm{Cd},{ }^{57} \mathrm{Co},{ }^{75} \mathrm{Se}$, and ${ }^{65} \mathrm{Zn}$. These radioisotopes were added to the media after first adding SupraPur $\mathrm{NaOH}$, yielding a final $\mathrm{pH}$ in the media of 8.0 to 8.1 (see Table 1 for information on exact chemical forms, activities of stocks, added concentrations and final experimental activities). The radioactive media were then innoculated with Thalassiosira pseudonana (initial concentration $1 \times 10^{4}$ cells $\mathrm{ml}^{-1}$ ) and allowed to grow for at least 6 divisions to late log-phase (about 3 to $4 \mathrm{~d})$ to ensure homogeneous labeling of the cells. Radiolabeled cells were then filtered, washed with unlabeled filtered SHSW, and resuspended in sterile-filtered SHSW.

Experimental set-up. The depuration chamber (Wang et al. 1995) consisted of a $30 \mathrm{l}$ glass aquarium containing ten $240 \mathrm{ml}$ plastic beakers suspended on grating above a 10 to 151 reservoir of $0.2 \mu \mathrm{m}$ filtered SHSW. Within each of the beakers was a plastic cylinder with $0.5 \mathrm{~cm}$ mesh netting suspended across the inner diameter of the cylinders at their midsection. Mussels were placed on top of this netting. This system eliminated the re-ingestion of labeled particulate metal associated with feces into the mussels by allowing their feces to pass downward into the bottom of the beaker and away from the mussels' siphons. Water was continually pumped from the reservoir into the cylinders containing the mussels. The water then passed down through the cylinder into the outer envelope of water, from where it eventually was returned to the reservoir via an overflow tube. Water was supplied to each beaker at a rate of 60 to $100 \mathrm{ml}$ $\mathrm{min}^{-1}$ or $>50$ times faster than the mussel filtration rates. Care was taken within each experiment to ensure that flow into each chamber was the same.

Prior to use in the experiments, mussels with shell lengths ranging between 20 and $24 \mathrm{~mm}$ had their shells thoroughly cleaned to remove as much epibiota as possible. Care was taken during all these manipulations to minimize exposures to large $\left(>5^{\circ} \mathrm{C}\right)$ changes in temperatures. The mussels were then transferred to an experimental depuration chamber and allowed to acclimate to the relevant experimental temperature for 10 to $14 \mathrm{~d}$ prior to the start of the experiment. Mussels were fed during both the acclimation and experimental depuration periods by pumping algal cells into the reservoirs at a fixed rate using a peristaltic pump. This suspension was placed into the incubator with the depuration chamber and continuously pumped into the reservoir at a rate of $8.2 \mathrm{ml} \mathrm{h}^{-1}$. There were 10 mussels in each depuration chamber, and the supply of food to each mussel in all experiments was $1.7 \mathrm{mg}$ dry wt $\mathrm{d}^{-1}$. As algal concentrations remained relatively unchanged over the course of the experiments, this rate approximates the feeding rate per mussel. Algae

Table 1. Mytilus edulis. Experimental parameters. SA: specific activity; Metal add.: amount added to algal cultures; Init. act.: initial activity; Temp.: temperate waters

\begin{tabular}{|c|c|c|c|c|c|c|}
\hline Expt & $\begin{array}{c}T \\
\left({ }^{\circ} \mathrm{C}\right)\end{array}$ & Source & Element & $\begin{array}{c}\mathrm{SA} \\
\left({\left.\mathrm{GBq} \mathrm{mg}^{-1}\right)}^{-1}\right.\end{array}$ & $\begin{array}{l}\text { Metal add. } \\
\left(\mathrm{nmol} \mathrm{l}^{-1}\right)\end{array}$ & $\begin{array}{c}\text { Init. act. } \\
\left(\mathrm{Bq} \mathrm{mussel}^{-1}\right)\end{array}$ \\
\hline 1 & 12 & Arctic & $\begin{array}{r}{ }^{100 \mathrm{~m}} \mathrm{Ag} \\
{ }^{241} \mathrm{Am} \\
{ }^{57} \mathrm{Co}\end{array}$ & $\begin{array}{l}0.02 \\
0.13 \\
1.94\end{array}$ & $\begin{array}{l}386 \\
22.4 \\
2.28\end{array}$ & $\begin{array}{c}12.6 \\
554 \\
22.8\end{array}$ \\
\hline 2 & 12 & Arctic & $\begin{array}{r}{ }^{109} \mathrm{Cd} \\
{ }^{75} \mathrm{Se} \\
{ }^{65} \mathrm{Zn}\end{array}$ & $\begin{array}{l}0.09 \\
0.05 \\
1.04\end{array}$ & $\begin{array}{c}150 \\
13.4 \\
15.4\end{array}$ & $\begin{array}{r}9.3 \\
6.0 \\
289\end{array}$ \\
\hline 3 & 2 & Arctic & $\begin{array}{r}{ }^{110 m} \mathrm{Ag} \\
{ }^{241} \mathrm{Am} \\
{ }^{57} \mathrm{Co}\end{array}$ & $\begin{array}{l}0.02 \\
0.13 \\
1.61\end{array}$ & $\begin{array}{r}421.5 \\
7.5 \\
0.92\end{array}$ & $\begin{array}{r}113 \\
242 \\
16\end{array}$ \\
\hline 4 & 2 & Arctic & $\begin{array}{c}{ }^{109} \mathrm{Cd} \\
{ }^{75} \mathrm{Se} \\
{ }^{65} \mathrm{Zn}\end{array}$ & $\begin{array}{l}0.07 \\
0.04 \\
0.84\end{array}$ & $\begin{array}{r}66.9 \\
9.1 \\
12.7\end{array}$ & $\begin{array}{c}47 \\
6.3 \\
335\end{array}$ \\
\hline 5 & 12 & Temp. & $\begin{array}{r}{ }^{110 \mathrm{~m}} \mathrm{Ag} \\
{ }^{109} \mathrm{Cd} \\
{ }^{65} \mathrm{Zn}\end{array}$ & $\begin{array}{l}0.01 \\
0.05 \\
0.33\end{array}$ & $\begin{array}{r}513 \\
164 \\
33\end{array}$ & $\begin{array}{c}1218 \\
20.8 \\
1506\end{array}$ \\
\hline 6 & 12 & Temp. & $\begin{array}{r}{ }^{241} \mathrm{Am} \\
{ }^{57} \mathrm{Co}\end{array}$ & $\begin{array}{c}0.13 \\
284.6\end{array}$ & $\begin{array}{l}15 \\
0.01\end{array}$ & $\begin{array}{l}1042 \\
90.5\end{array}$ \\
\hline 7 & 12 & Temp. & $\begin{array}{r}{ }^{110 \mathrm{~m}} \mathrm{Ag} \\
{ }^{109} \mathrm{Cd} \\
{ }^{75} \mathrm{Se}\end{array}$ & $\begin{array}{l}0.01 \\
0.04 \\
0.74\end{array}$ & $\begin{array}{r}1049 \\
164 \\
69\end{array}$ & $\begin{array}{r}273 \\
41.8 \\
66.5\end{array}$ \\
\hline 8 & 2 & Temp. & $\begin{array}{r}{ }^{110 \mathrm{~m}} \mathrm{Ag} \\
{ }^{241} \mathrm{Am} \\
{ }^{57} \mathrm{Co}\end{array}$ & $\begin{array}{c}0.01 \\
0.13 \\
284.6\end{array}$ & $\begin{array}{r}1100 \\
15 \\
0.01\end{array}$ & $\begin{array}{r}790 \\
573 \\
48\end{array}$ \\
\hline 9 & 2 & Temp. & $\begin{array}{c}{ }^{{ }^{109} \mathrm{Cd}} \\
{ }^{75} \mathrm{Se} \\
{ }^{65} \mathrm{Zn}\end{array}$ & $\begin{array}{l}0.04 \\
0.67 \\
0.33\end{array}$ & $\begin{array}{c}164 \\
0.43 \\
32\end{array}$ & $\begin{array}{r}574 \\
115 \\
3008\end{array}$ \\
\hline
\end{tabular}


in the stock flask were kept suspended using a stirring bar and the reservoir was vigorously and continuously mixed using air stones to ensure an even distribution of algae to all mussels. The algal stocks were replaced every 2 to $4 \mathrm{~d}$.

Mussel filtering rates in the experiments with the mussels from the Arctic were estimated by measuring the steady-state concentration of algae in depuration chambers using a Coulter Counter Multisizer II system. Cell concentrations and cell sizes in incoming feeding stock suspensions were measured, as were concentrations in the depuration chamber over time after beginning the supply of algae. These concentrations were used to estimate filtration rates using the equation:

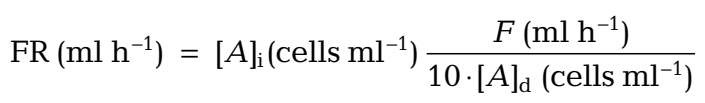

where FR $=$ filtration rate, $[A]_{\mathrm{i}}$ and $[A]_{\mathrm{d}}=$ cell concentrations in inflow and feeding chamber, respectively, $F=$ flow rate of incoming water, and $10=$ number of mussels in the feeding chamber.

A fluorometer was available for use during the experiments with the temperate mussels, allowing us to efficiently assess filtration rates for each individual rather than the average value for all 10 mussels. The mussels were placed individually in $250 \mathrm{ml}$ containers containing $200 \mathrm{ml}$ of $0.2 \mu \mathrm{m}$ filtered SHSW. After allowing $1 \mathrm{~h}$ for acclimation, Thalassiosira pseudonana cells were added and the in vivo fluorescence in $4 \mathrm{ml}$ aliquots was monitored over the course of 1 to $2 \mathrm{~h}$ using a Turner designs Model 10AU fluorometer. The algal concentrations were always kept well below the incipient limiting concentration for Mytilus edulis to ensure maximal filtration by the mussels. The use of small chambers allowed quick determination of filtration rates $(<0.5 \mathrm{~h})$, and made it unnecessary to agitate the feeding solution, since pumping by the mussels was sufficient to effectively mix the chambers after several minutes. Filtration rates were estimated by regressing the natural logarithm of the in vivo fluorescence versus time over periods of linear decline and multiplying the resulting slope by $200 \mathrm{ml}$. We had found in previous experiments that, over the span of one of our feeding experiments, the rate of change in in vivo fluorescence is strongly correlated and directly proportional with changing cell numbers, as determined with a Coulter counter $\left(\mathrm{r}^{2}>0.98\right)$. The experimental temperatures chosen were 2 and $12^{\circ} \mathrm{C}$, since this range spans most of that experienced by the Arctic mussels during the course of a year (Lars Føyn pers. comm.).

Radiotracer pulse-chase experiments. Prior to the feeding-pulse stage, mussels were removed from the depuration chambers, quickly cleaned and placed into the center of $1 \mathrm{l}$ polyethylene beakers containing
$500 \mathrm{ml}$ of sterile-filtered SHSW that had been chilled to the experimental temperature. The experimental temperature was maintained by either keeping the mussels in the temperature-controlled incubator (the $12^{\circ} \mathrm{C}$ experiments) or holding them in ice-baths (the $2^{\circ} \mathrm{C}$ experiments). Water temperatures during these manipulations were monitored using a submersible watertemperature logger (Onset Corporation). After allowing the mussels to adapt to this new environment for $1 \mathrm{~h}$, radiolabeled diatoms (resuspended and rinsed) were added at a concentration of $1 \times 10^{4}$ cells ml $^{-1}$ (or $0.2 \mathrm{mg}$ dry $\mathrm{wt}^{-1}$ ), a concentration well below that $\left(>5 \mathrm{mg} \mathrm{l}^{-1}\right.$ ) reported to cause pseudofeces by these mussels (Widdows et al. 1979). The water in the beakers was mixed and the mussels allowed to feed for either $0.5 \mathrm{~h}\left(\right.$ at $\left.12^{\circ} \mathrm{C}\right)$ or $1 \mathrm{~h}\left(\right.$ at $\left.2^{\circ} \mathrm{C}\right)$. The mussels were then removed from solution, rinsed with SHSW of the appropriate temperature, and placed within $120 \mathrm{ml}$ polyethylene sampling containers containing $60 \mathrm{ml}$ of 2 or $12^{\circ} \mathrm{C}$ water.

Each counting container containing a mussel was successively placed into a deep-well $\mathrm{NaI}(\mathrm{Tl})$ detector (Canberra Instruments) to measure gamma emissions while the other mussels were maintained at fixed temperature in the incubators. X-rays emissions of the short-lived daughter product ${ }^{109} \mathrm{Cd}\left({ }^{109} \mathrm{Ag}\right.$ [half life] $)$ were assayed at 22 to $26 \mathrm{keV}$, while gamma emissions of ${ }^{241} \mathrm{Am},{ }^{75} \mathrm{Se}$, and ${ }^{65} \mathrm{Zn}$ were assayed at 60,279 and $1115 \mathrm{keV}$, respectively. Gamma emissions of ${ }^{110 \mathrm{~m}} \mathrm{Ag}$ were at assayed at 657 and $884 \mathrm{keV}$. Background values were subtracted and counting times were adjusted to as short as possible to keep temperature change to a minimum while achieving a relative standard deviation of $<10 \%$. After counting, the mussels and the contents of the counting chambers were transferred to beakers within the depuration chamber and the supply of algal food to the chamber reservoir was begun. Recycling of radiolabel was kept to a minimum by replacing the reservoir water after the first day (when efflux of radiolabel was maximal), and every 3 to $7 \mathrm{~d}$ thereafter. Gamma-spectroscopy of unlabeled mussels in the depuration chambers revealed that mussels did not accumulate significant radiolabel from the recirculating water.

At intervals, all mussels were transferred from the depuration chambers into the counting containers with new filtered SHSW, and the counting procedure was repeated. The intervals varied among experiments, but were generally more frequent early in the experiment to enable characterization of the rapid loss of radiotracer during defecation, and less frequent later in the experiment when the rate of loss slowed. The experiments continued until a log-linear efflux trend for loss of radiotracer from the mussels could be accurately determined. Also, at each time point the contents of the 
depuration beakers were assayed for radioactivity associated with feces using a Wallac-Pharmacia LKB $\mathrm{NaI}(\mathrm{Tl})$ gamma spectrometer and counted as described above for $15 \mathrm{~min}$ (Wang et al. 1995). At the end of the experiments, the mussels were frozen and the soft parts removed from the shells. Dry weights were determined for the soft parts after drying to a constant weight at $60^{\circ} \mathrm{C}$, and radioactivity associated with shell and soft tissues was determined (Fisher et al. 1996).

Calculations and statistical treatment. Wang et al. (1996) found that efflux from the slowest turnover pool of most metals could be well-described by a simple exponential loss process beginning 6 to $8 \mathrm{~d}$ after feeding. In our experiments, the exponential loss rate was essentially constant after $8 \mathrm{~d}$ in the experiments with temperate mussels, and after $6 \mathrm{~d}$ in the experiments with Arctic mussels. Therefore, we determined $k_{\mathrm{e}}$ as the slope of the natural logarithm of the percent radiolabeled retained against time for data taken after these time points. The intercept of the resulting lines was taken as the best estimate of assimilation into the pool with the slowest turnover.

We also assessed the potential for the mussels to biomagnify metal from their food by calculating the trophic accumulation factor, TAF (the bioaccumulation factor, or BAF, of Reinfelder et al. 1998, where BAF = $\mathrm{AE} / \mathrm{k}_{\mathrm{e}}$ ). In the case of $\mathrm{Ag}$ (and possibly $\mathrm{Am}$ ) in the $2{ }^{\circ} \mathrm{C}$ experiment with temperate mussels, efflux of radiolabel from the mussels increased after $8 \mathrm{~d}$. For the purposes of comparison we have used only the data between Days 4 and 8 to calculate the $k_{\mathrm{e}}$ and the AE for our experiment. Gut passage time (GPT) was taken to be the time at which $90 \%$ of the total amount of defecated radiolabel had passed from the mussels. The exact value was calculated from the plot of cumulative radiolabel defecated against time by linear interpolation. Because of a combination of low specific activity of some radiolabel and low defecation due to high AEs, reliable GPT estimates under all experimental conditions were only available for $\mathrm{Am}, \mathrm{Cd}$ and $\mathrm{Zn}$. The mean and standard error for $k_{\mathrm{e}}, \mathrm{AE}, \mathrm{TAF}$ and GPT were determined using the separate estimates for the 5 mussels used in each experiment.

The effect of temperature and geographic source of the population on all 3 biokinetic parameters was determined using for each metal using 2-way analyses of variance (ANOVAs) with temperature and population origin as predictor-class variables, and for all metals combined using 3-way ANOVAs that employed temperature, population origin and element as predictor classes. It was necessary to logarithmically transform the variables to meet the assumptions of normality and homogeneity of variance. Except for Ag, for which we could not determine the kinetic parameters for one of the experiments due to low radioactivity in the mussels at the end of the defecation period, an interaction term was included to assess the importance of differences among the experiments that were not related to the variables of interest. Because of the large number of statistical comparisons, a critical p-value of 0.01 was used as an arbitrary threshold for significance to reduce the frequency of Type II errors. However, we also report all $\mathrm{p}$-values here.

\section{RESULTS}

Using the equilibrium algal cell density, we determined from Eq. (1) that the Arctic mussels filtered water at a rate of $828 \pm 45 \mathrm{ml}$ ind. ${ }^{-1} \mathrm{~h}^{-1}$ at $12^{\circ} \mathrm{C}$, and $652 \pm$ $17 \mathrm{ml}$ ind. ${ }^{-1} \mathrm{~h}^{-1}$ at $2^{\circ} \mathrm{C}$. Feeding rate experiments with temperate mussels yielded similar results $-984 \pm 62 \mathrm{ml}$ ind..$^{-1} \mathrm{~h}^{-1}$ at $12^{\circ} \mathrm{C}$ and $669 \pm 73 \mathrm{ml}$ ind.$^{-1} \mathrm{~h}^{-1}$ at $2^{\circ} \mathrm{C}$.

As typical during depuration in pulse-chase radiotracer experiments, the radiolabel retained by the mussels remained near $100 \%$ for a short interval $(<0.25 \mathrm{~d})$, before declining rapidly as the ingested radiolabel began to be defecated (Fig. 1). This period of rapid loss usually lasted $<3 \mathrm{~d}$ and was followed by a period of slower exponential loss. Loss rates of radioactivity in fecal material generally mirrored this pattern (Fig. 2). Differences were apparent between the radioisotope depuration curves at 2 and $12^{\circ} \mathrm{C}$ (Fig. 1). Generally, the radioactivity retained by the mussels near the end of the $2^{\circ} \mathrm{C}$ experiments was higher than in the $12^{\circ} \mathrm{C}$ experiments after approximately the same period of depuration. Some metals seemed to be retained longer in the gut than others, as reflected in differences among calculated GPTs of various metals (Fig. 3).

When averaged over all experiments, the geometric mean GPTs for Am (0.6 d), Cd $(0.8 \mathrm{~d})$ and $\mathrm{Zn}(1.0 \mathrm{~d})$, the 3 elements for which GPT could be estimated in all experiments, were significantly different $(p<0.0003)$ from each other. GPTs averaged about $80 \%$ longer at $2^{\circ} \mathrm{C}$ than at $12^{\circ} \mathrm{C}(\mathrm{p}<0.0001$ based on a 2 -way full factorial ANOVA). The GPT values for $\mathrm{Cd}$ and $\mathrm{Zn}$ were 2.5 and 3.7 times as long, respectively, in the Arctic mussels as in the temperate mussels $(p<0.0001)$, but the average GPT values for Am did not differ between the 2 populations. At the end of the experiments, most of the radiolabel was found in the soft tissues rather than the shells of the mussels; only $25 \%$ of Am, $15 \%$ of $\mathrm{Ag},<10 \%$ of $\mathrm{Se}, \mathrm{Zn}$ and $\mathrm{Co}$ and $<2 \%$ of $\mathrm{Cd}$ were found in the mussel shells at the end of the experiment (Fig. 4).

The elements that were assimilated least efficiently in all experiments were Am (range in means for experiments $=2$ to $13 \%$ ) and Ag (2 to $19 \%$ ) (Table 2). At the other extreme, AEs for Se (39 to $79 \%$ ) were consistently among the highest, as were those for Co (62 to 


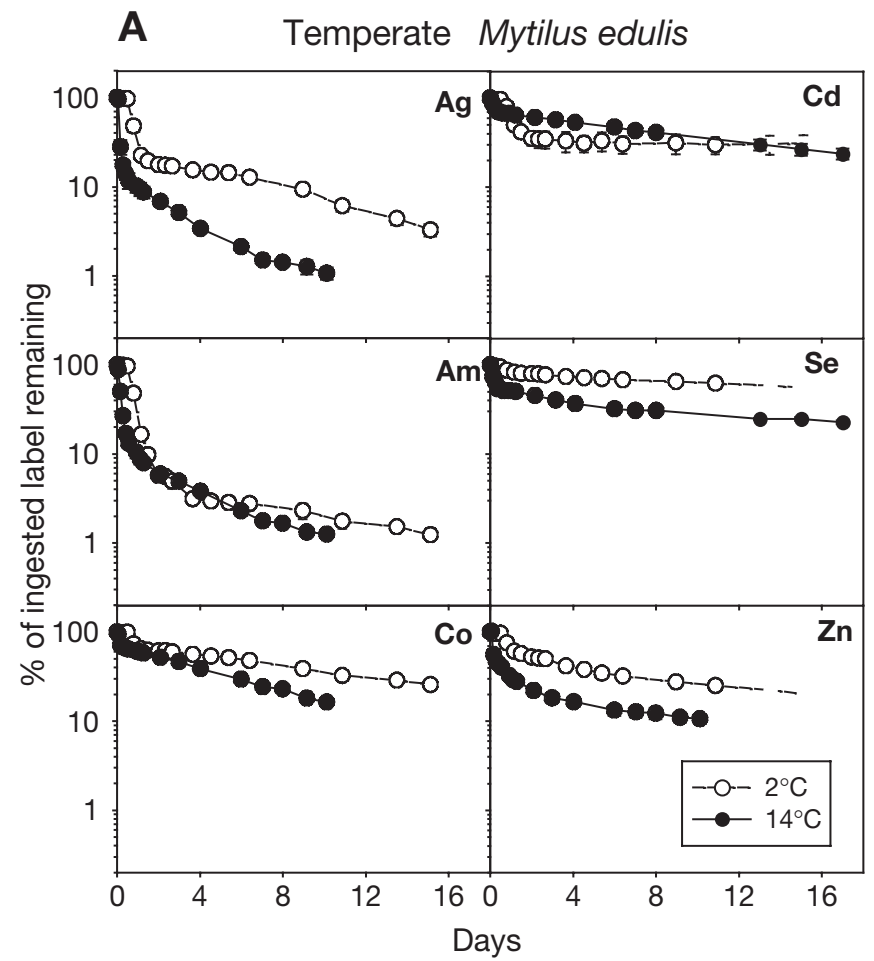

B Arctic Mytilus edulis

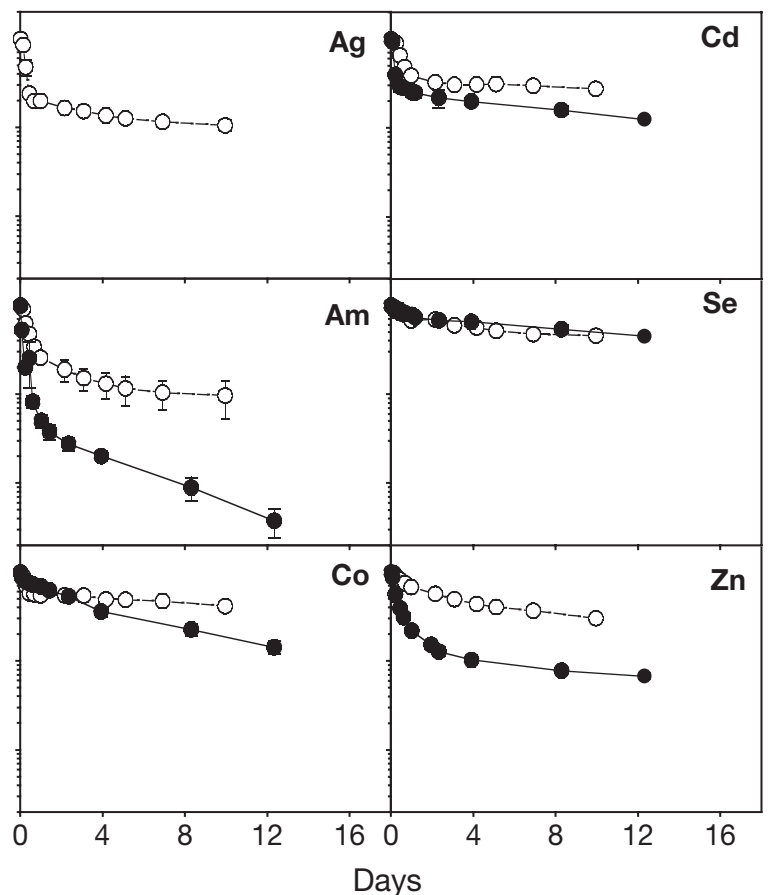

Fig. 1. Mytilus edulis. Time series of radioisotope depuration during pulse-chase experiments for mussels from (A) temperate waters (Long Island Sound) and (B) from above Arctic Circle in Norway. Each symbol represents the mean of 5 replicate observations. Error bars are $\pm 1 \mathrm{SE}$. Where error bars are invisible, they are smaller than the symbols

A

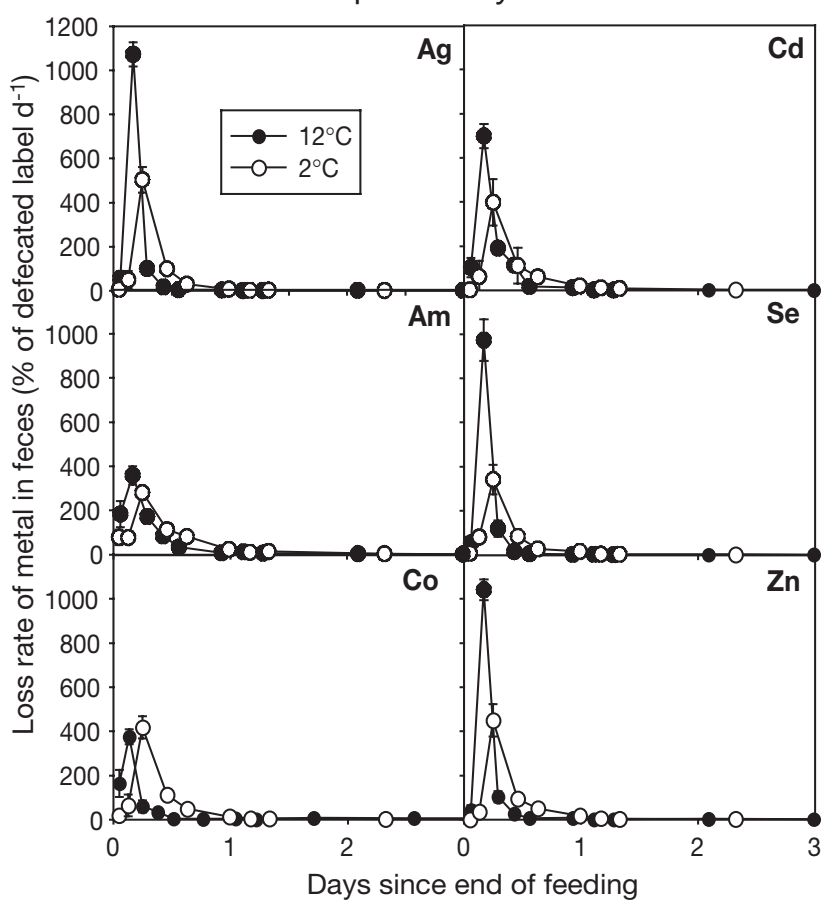

B

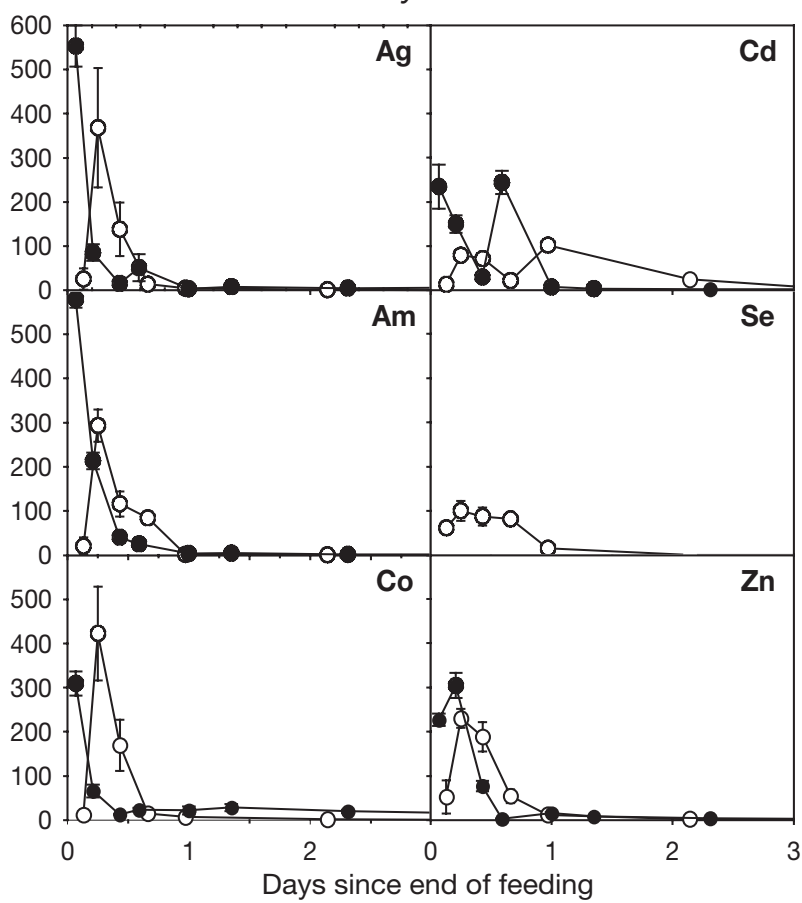

Fig. 2. Mytilus edulis. Time series of loss of radioisotope in feces during pulse-chase experiments for mussels from (A) temperate waters (Long Island Sound) and (B) from above Arctic Circle in Norway. Loss described as rate relative to total amount ingested and may exceed $100 \%$ for short intervals without violating conservation of mass. Further details as in Fig. 1 


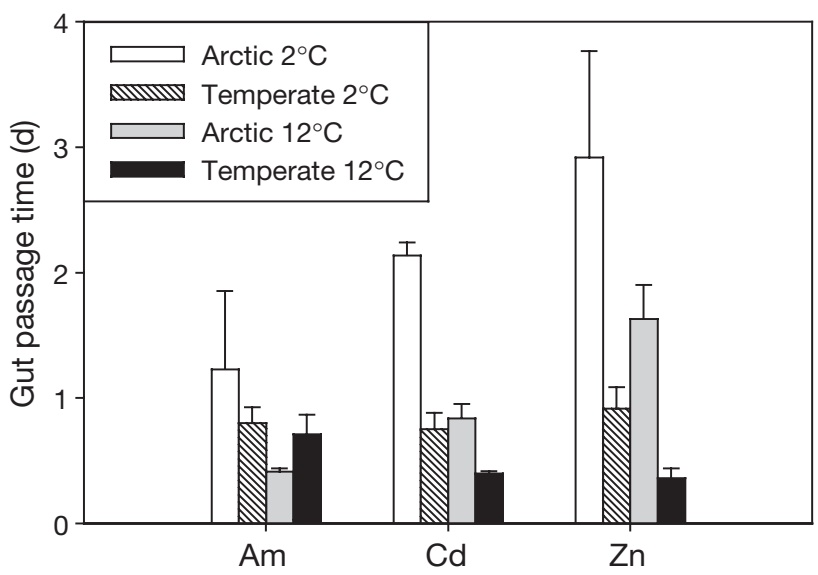

Fig. 3. Mytilus edulis. Gut-passage times representing time necessary for $90 \%$ of total radiolabel defecated to pass from gut. Data are means $( \pm 1 \mathrm{SE})$ of replicate observations

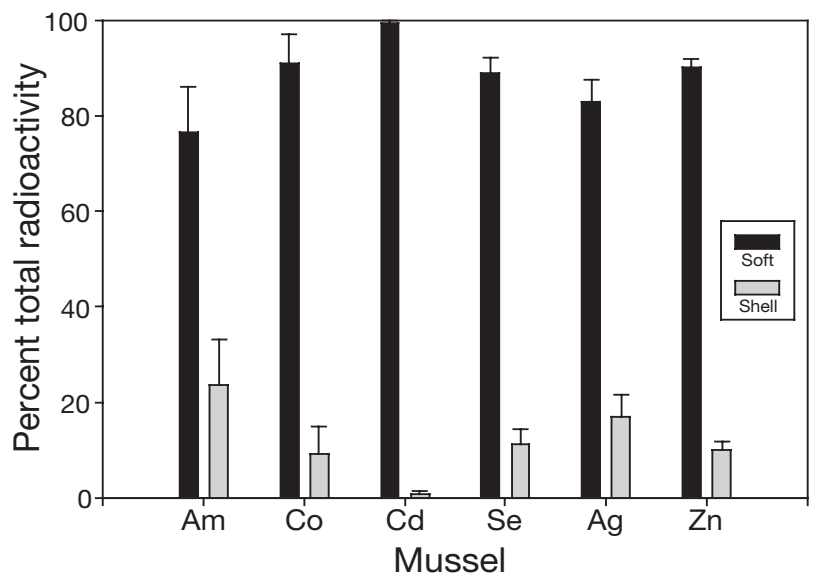

Fig. 4. Mytilus edulis. Percentage of radiolabel associated with soft tissues and shell at end of depuration period. Data are means $( \pm 1 \mathrm{SE})$ of replicate observations

Cd assimilation typically ranged between 25 and $35 \%$, except for the temperate mussels at $12^{\circ} \mathrm{C}$ for which assimilation averaged $67 \%$. The overall ANOVAs (Table 3) indicate that differences among elements explained by far the most variability in $\mathrm{AE}$, followed by temperature and population origin, with the former explaining almost 4 -fold more variance than the latter. Significant interactions between temperature and element, and population origin and element indicated that the effects of temperature and population origin differed among the elements. Element-specific ANOVAs revealed that temperature and geographic origin together could explain a significant fraction (56 to $91 \%$ ) of the variance in $\mathrm{AE}$ for every element (Table 4). Temperature had a significant impact on the AEs for all but 1 of the elements, explaining 10 to $92 \%$ of the variance. In each case, $\mathrm{AE}$ was lower at the warmer temperature, with the largest effects being for Ag (10.5-fold difference) and Zn (3.5-fold difference). More modest differences were seen for Se (1.2-fold), Co (1.4-fold) and Am (2.2-fold). Population origin was related to AE for only Co and Am, for which assimilation by Arctic mussels was 1.4- and 2.8-fold more efficient, respectively. There were strong and significant interaction terms for $\mathrm{Cd}$, Co and Se. The logarithm of GPT had a significant positive effect on $\mathrm{AE}$ when data for $\mathrm{Am} \mathrm{Cd}$ and $\mathrm{Zn}$ were combined (slope $=0.54, \mathrm{p}=0.02, \mathrm{n}=59$ ), but this relationship explained only $7 \%$ of the variance in $\mathrm{AE}$ for these metals.

During the period of slowest loss, $k_{\mathrm{e}}$ was $<7 \%$ $\mathrm{d}^{-1}$, except for $\mathrm{Co}$ and $\mathrm{Am}$ in the $12^{\circ} \mathrm{C}$ experi- 


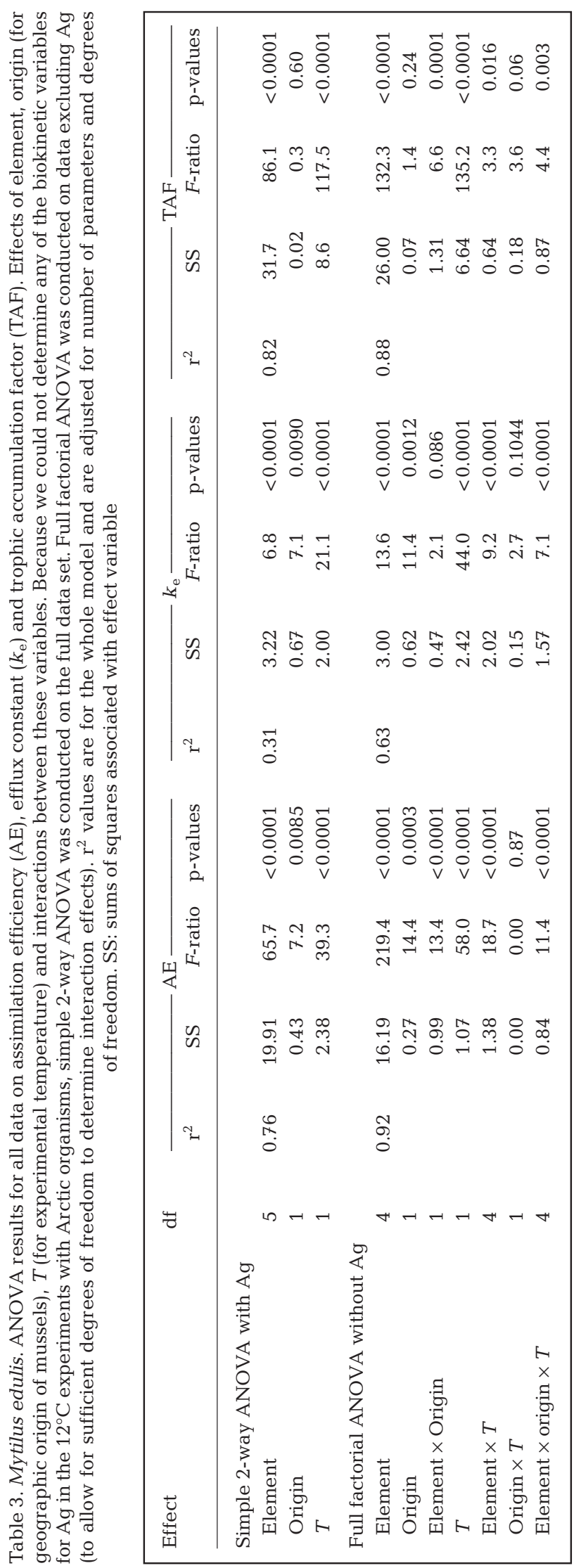

ments with the Arctic mussels, for which loss was measured at 12.7 and $21.5 \% \mathrm{~d}^{-1}$, respectively (Table 2). Other values ranged from $2.5 \% \mathrm{~d}^{-1}$ for $\mathrm{Cd}$ to $6.4 \% \mathrm{~d}^{-1}$ for Co. Relative variation in $k_{\mathrm{e}}$ among experiments for Am (1.6-fold), Se (2.5-fold), and Zn (2-fold), was relatively small, while Co (3.7-fold), Ag (6.1-fold), and especially Cd (12.6-fold) exhibited much greater relative variation (Table 2). The ANOVAs lumping all elements together indicated that differences in $k_{\mathrm{e}}$ among elements were a significant source of variability, but element specific differences in $k_{\mathrm{e}}$ were less pronounced and less systematic than for AE (Table 3). More than 4 times more variability in $k_{\mathrm{e}}$ could be explained by temperature than by geographic origin of the population. Moreover, all the significant interaction terms included temperature, whereas the only significant interaction term that included population origin was the interaction between all 3 predictors. Element specific ANOVAs revealed that temperature and geographic origin combined could explain significant ( $\mathrm{p}=0.01$ level) variability in $k_{\mathrm{e}}$ for $\mathrm{Co}, \mathrm{Cd}$, and $\mathrm{Zn}$. The effect of temperature on $k_{\mathrm{e}}$ for Am $(\mathrm{p}=0.017)$ and Se $(p=0.02)$ was of borderline significance (Table 5). In all these cases, the effect of temperature was far more important than that of population origin, although for Co the interaction term was also significant and as important as the effect of temperature. In most cases where temperature had a significant effect, $k_{\mathrm{e}}$ was higher at $12^{\circ} \mathrm{C}$ than at $2^{\circ} \mathrm{C}$. The exception was $\mathrm{Zn}$, for which the opposite was true.

Trophic accumulation factors (TAF) were lowest for Am (range of experiment means $=0.2$ to 5.1) and Ag (0.6 to 3.5), reflecting their low AEs and relatively fast loss from tissues (Fig. 5). TAF was highest for $\mathrm{Cd}$ ( 5 to 66 ) and Se (12 to 43 ), with Co (5 to 24$)$ and $\mathrm{Zn}$ (2.5 to 9.6) being slightly lower. The ANOVAs including all

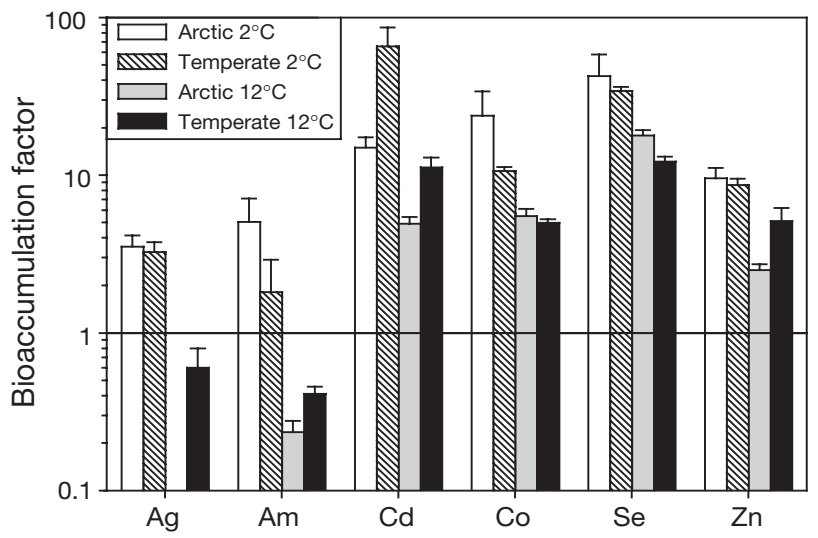

Fig. 5. Mytilus edulis. Variation in trophic accumulation factor as a factor of element, experimental temperature and population source. Data are means $(+1 \mathrm{SE})$ of 5 replicate observations 
Table 4. Mytilus edulis. Results of ANOVA on assimilation efficiency (AE). The 2 levels for source population effect were Arctic and temperate; the 2 levels for temperature effect were 2 and $12^{\circ} \mathrm{C}$. Effect size for geographic origin calculated as percentage difference according to ([Arctic $\mathrm{AE}] /[$ temperate $\mathrm{AE}]-1) \times 100$, and effect size of experimental temperature as $\left(\left[2^{\circ} \mathrm{C} \mathrm{AE}\right] /\left[12^{\circ} \mathrm{C} \mathrm{AE}\right]-\right.$ 1) $\times 100$. Model $\mathrm{r}^{2}$ values adjusted for number of parameters and observations and presented as percentages. Partial $\mathrm{r}^{2 `} \mathrm{~s}$ calculated as percentage of total sum of squares accounted for by Type II SSs associated with effect variable (see last subsection of 'Materials and methods'). Model and effect values associated with $\mathrm{p}$-values $<0.01$ are in boldface

\begin{tabular}{|c|c|c|c|c|c|c|c|c|c|c|}
\hline \multirow[t]{2}{*}{ Element } & \multicolumn{2}{|c|}{ - Whole model - } & \multicolumn{3}{|c|}{ — Population source $ـ$} & \multicolumn{3}{|c|}{ - Temperature -} & \multicolumn{2}{|c|}{ _ Interaction } \\
\hline & $\mathrm{r}^{2}$ & $\mathrm{p}$ & Effect $(\% \Delta)$ & Partial r ${ }^{2}$ & $\mathrm{p}$ & Effect $(\% \Delta)$ & Partial r ${ }^{2}$ & $\mathrm{p}$ & Partial $r^{2}$ & $\mathrm{p}$ \\
\hline $\mathrm{Ag}$ & 93.1 & $<0.0001$ & -17 & 0.5 & 0.34 & 945 & 76.2 & $<0.0001$ & & \\
\hline $\mathrm{Am}$ & 58.8 & 0.0006 & 177 & 39.7 & 0.0006 & 122 & 24.2 & 0.0042 & 1.4 & 0.43 \\
\hline $\mathrm{Cd}$ & 56.2 & 0.0009 & -31 & 14.9 & 0.022 & -23 & 7.0 & 0.1006 & 41.3 & 0.0006 \\
\hline $\mathrm{Co}$ & 71.4 & $<0.0001$ & 41 & 22.6 & 0.0013 & 38 & 19.6 & 0.0024 & 33.7 & 0.0002 \\
\hline $\mathrm{Se}$ & 80.7 & $<0.0001$ & 19 & 7.8 & 0.014 & 21 & 9.6 & 0.0073 & 66.4 & $<0.0001$ \\
\hline $\mathrm{Zn}$ & 92.6 & $<0.0001$ & 2 & 0.0 & 0.81 & 277 & 92.2 & $<0.0001$ & 1.5 & 0.066 \\
\hline
\end{tabular}

Table 5. Mytilus edulis. Results of ANOVA on efflux constant. Variables as in Table 4

\begin{tabular}{|c|c|c|c|c|c|c|c|c|c|c|}
\hline \multirow{2}{*}{ Element } & \multicolumn{2}{|c|}{ - Whole model - } & \multicolumn{3}{|c|}{ — Population source -} & \multicolumn{3}{|c|}{ — Temperature } & \multicolumn{2}{|c|}{ Interaction } \\
\hline & $\mathrm{r}^{2}$ & $\mathrm{p}$ & Effect $(\% \Delta)$ & Partial $\mathrm{r}^{2}$ & $\mathrm{p}$ & Effect $(\% \Delta)$ & Partial $\mathrm{r}^{2}$ & $\mathrm{p}$ & Partial $r^{2}$ & $\mathrm{p}$ \\
\hline $\mathrm{Ag}$ & 0.0 & 0.5 & -23 & 3.1 & 0.53 & 62 & 10.7 & 0.25 & & \\
\hline $\mathrm{Am}$ & 35.6 & 0.018 & 112 & 12.0 & 0.078 & -66 & 24.2 & 0.017 & 9.6 & 0.11 \\
\hline $\mathrm{Cd}$ & 90.9 & $<0.0001$ & 103 & 11.7 & 0.0002 & -80 & 61.3 & $<0.0001$ & 19.4 & $<0.0001$ \\
\hline Co & 50.2 & 0.0025 & 5 & 0.1 & 0.82 & -48 & 29.3 & 0.0041 & 28.6 & 0.0045 \\
\hline $\mathrm{Se}$ & 21.3 & 0.079 & 1 & 0.0 & 0.96 & -46 & 27.6 & 0.02 & 6.2 & 0.24 \\
\hline $\mathrm{Zn}$ & 42.7 & 0.0075 & 36 & 17.7 & 0.028 & 46 & 27.2 & 0.0084 & 6.7 & 0.15 \\
\hline
\end{tabular}

Table 6. Mytilus edulis. Results of ANOVA on trophic accumulation factor (assimilation efficiency/efflux constant). Variables as in Table 4

\begin{tabular}{|c|c|c|c|c|c|c|c|c|c|c|}
\hline \multirow[t]{2}{*}{ Element } & \multicolumn{2}{|c|}{ - Whole model - } & \multicolumn{3}{|c|}{ — Population source -} & \multicolumn{3}{|c|}{ Temperature } & \multicolumn{2}{|c|}{ _ Interaction } \\
\hline & $\mathrm{r}^{2}$ & $\mathrm{p}$ & Effect $(\% \Delta)$ & Partial $\mathrm{r}^{2}$ & $\mathrm{p}$ & Effect $(\% \Delta)$ & Partial $\mathrm{r}^{2}$ & $\mathrm{p}$ & Partial $r^{2}$ & $\mathrm{p}$ \\
\hline $\mathrm{Ag}$ & 75.2 & $<0.0001$ & 8 & 0.1 & 0.83 & 546 & 56.7 & 0.0001 & & \\
\hline $\mathrm{Am}$ & 61.0 & 0.0004 & 35 & 1.5 & 0.41 & 522 & 53.0 & 0.0001 & 12.8 & 0.024 \\
\hline $\mathrm{Cd}$ & 85.0 & $<0.0001$ & -66 & 31.9 & $<0.0001$ & 291 & 50.8 & $<0.0001$ & 2.3 & 0.14 \\
\hline $\mathrm{Co}$ & 57.8 & 0.0007 & 35 & 5.3 & 0.14 & 165 & 56.2 & 0.0001 & 3.0 & 0.23 \\
\hline Se & 46.8 & 0.0042 & 18 & 2.0 & 0.41 & 126 & 49.7 & 0.0007 & 3.5 & 0.28 \\
\hline $\mathrm{Zn}$ & 71.7 & $<0.0001$ & -25 & 5.5 & 0.072 & 159 & 62.1 & $<0.0001$ & 8.8 & 0.023 \\
\hline
\end{tabular}

elements indicated that TAF varied primarily among elements and by temperature (Table 3). While some interaction terms were significant, they were also relatively unimportant based on their partial $\mathrm{r}^{2}$ values. All element-specific ANOVAs predicting elemental TAFs from the experimental temperature and the geographical source of population were significant ( $\mathrm{p} \leq 0.0005$, Table 6), and in each case temperature was not only significant but was also the predictor with the greatest effect on TAF. The TAFs for Am and Ag were the most sensitive to temperature, being $>6$-fold higher at $2{ }^{\circ} \mathrm{C}$ than at $12^{\circ} \mathrm{C}$. The TAF for Cd was the next most sensitive to temperature, being almost 4 -fold higher at the colder temperature, while TAFs for Co, Se and Zn were all between 2- and 3-fold higher. Only for Cd was geo- graphic origin a significant predictor of TAF, with the Arctic mussels having $66 \%$ lower TAFs than the temperate mussels. In contrast to $\mathrm{AE}$ and $k_{\mathrm{e}}$, no interaction effects were significant for TAF.

\section{DISCUSSION}

\section{Effect of temperature on biokinetic parameters}

Some metals reach elevated concentrations in marine Arctic organisms even though outwardly, polar regions appear to be pristine (Dietz et al. 1998, Strand 1998, Fisher et al. 1999). This may be due to an enhanced supply of contaminants to the region via atmospheric 
or advective transport, dumping or accidental releases, or enhanced accumulation at the base of the food chain. However, there is also a possibility that Arctic marine organisms, either because of characteristics of their environment or due to genotypic adaptation to that environment, may be more effective at concentrating metal from food. Temperature may be expected to affect uptake and retention of metals from food in marine organisms. In poikilotherms (which usually occupy lower positions in marine food webs), ingestion rate, digestive processing time and metabolic rate may all be affected by temperature, and these could all influence the concentration of metals within tissues (Bayne \& Newell 1983, Jørgensen 1990).

Our results indicate that the net effect of environmental temperature on bioaccumulation needs to be considered when assessing the potential for invertebrates such as mussels to accumulate metal contaminants from food. Without exception, the metal trophic accumulation factor (TAF) values were higher at $2{ }^{\circ} \mathrm{C}$ than at $12^{\circ} \mathrm{C}$. The variability in TAF values attributable to temperature was not as large as the 30 -fold variability in TAF among elements, but was much larger than any other source of variability accounted for in these experiments.

In a seeming paradox, there was no similarly uniform effect of temperature on the 2 biokinetic parameters that determine the TAF. While temperature always had a larger effect than population origin on $\mathrm{AE}$ and $k_{\mathrm{e}}$ in the ANOVAs that included all elements, for individual elements the effect was more variable and often not significant. The combination of a strong and unidirectional temperature effect on the TAF and less uniform temperature effects on $\mathrm{AE}$ and $k_{\mathrm{e}}$ may result from a kind of temperature dependent homeostasis or regulation of tissue metal concentrations. If assimilation of a particular metal is very sensitive to temperature, as it is for $\mathrm{Zn}$, a metal whose tissue concentrations are regulated in mussels (Wang et al. 1996), then the high efflux at the lower temperature may compensate for the relatively high influx at that temperature.

In other cases, complex variations in $\mathrm{AE}$ and $k_{\mathrm{e}}$ among the individual experiments combined to cause a simple response in the TAF to temperature. For example, unusually low AE in one experiment was sometimes compensated for by an unusually low $k_{\mathrm{e}}$ as for Se and $\mathrm{Co}$ in the temperate mussels at $12^{\circ} \mathrm{C}$. Am showed a different pattern still, with an unusually high assimilation by Arctic mussels at $2^{\circ} \mathrm{C}$ and a fast efflux at $12^{\circ} \mathrm{C}$, combining to result in uniformly higher TAF values at low temperatures. Thus, one interpretation of these distinct patterns is that the mussels, in a manner broadly and perhaps indirectly determined by temperature, are altering their excretion rates based in part on the amount of metal assimilated from food. While
AE and GPT are influenced somewhat by temperature, other factors, such as population origin, also affect assimilation and obscure the effect of temperature and GPT on AE. However, these non-temperature related variations in $\mathrm{AE}$ appear to be compensated for by corresponding changes in $k_{\mathrm{e}}$, causing the response of TAF to temperature to be rather uniform.

The sensitivity of the TAF to a particular metal to temperature is correlated to the degree to which that element is biologically necessary. The metals most sensitive to temperature were Ag and Am, for which the TAF was over 6-fold higher at colder temperatures. Both of these metals are very particle-reactive (Fisher 1986) and tend to partition largely to algal cell surfaces (Reinfelder \& Fisher 1991), and neither has any known biological function. Neither of these metals typically displays appreciable assimilation by marine invertebrates from food (Fisher \& Reinfelder 1995, Wang \& Fisher 1999). In contrast, the elements whose TAF values were least sensitive to temperature, Zn, Se and Co, are also those with strong biological roles- $\mathrm{Zn}$ as a cofactor in many enzymes and as a structuring agent in finger proteins, Se as a component of certain forms of glutathione peroxidase, and Co in cobalamine (the association of Co with cobalamine in the food algae is strongly suggested by the high AEs for this element, consistent with earlier findings: Nolan et al. 1992). These metals tend to partition more into cellular cytoplasm of algae (Reinfelder \& Fisher 1991), and typically show correspondingly higher assimilation in mussels than Ag and Am (Wang \& Fisher 1999). TAFs for these metals were between 2- and 4-fold higher at colder temperatures, suggesting that their concentrations in tissues were more closely regulated by the mussels. Cd had an intermediate sensitivity to temperature, with an almost 4 -fold increase in TAF at the colder temperature. Cd falls somewhere between the other 2 groups of metals in terms of its biological role. Cd is less particle-reactive in seawater than Am and Ag (Fisher 1986), but once associated with cells it does enter into cytoplasm (Reinfelder \& Fisher 1991), and displays appreciable assimilation in herbivores (Wang \& Fisher 1999) despite its limited biological requirement as substitute for other metals in some algal enzymes (Lee \& Morel 1995).

Any interpretation of temperature-related changes in TAF in terms of the actual potential for biomagnification of dietary metal by mussels needs also to take into account the possible effect of temperature on ingestion rates. Actual biomagnification of metal from food can be predicted by the equation

$$
[X]_{\mathrm{m}}{ }^{*} /[X]_{\mathrm{f}}=B M^{*}=\mathrm{IR} \cdot \mathrm{AE} /\left(k_{\mathrm{e}}+g\right)
$$

where $[X]_{\mathrm{m}}{ }^{*}$ is the predicted steady state metal concentration in mussel tissue, $[X]_{\mathrm{f}}$ is the metal concentra- 
tion in the algal food, $B M^{*}$ is the steady state ratio of the 2 previous values, IR is ingestion rate ( $g$ dry wt food $\mathrm{g}^{-1}$ dry wt mussel $\mathrm{d}^{-1}$, and $g$ is the growth rate $\left(\mathrm{d}^{-1}\right)$. Assuming that $g$ is slow relative to $k_{\mathrm{e}}, B M^{*}=\mathrm{TAF} \times \mathrm{IR}$. IR was held constant in our experiments by fixing the supply rate of algae and allowing cell concentrations to vary until an equilibrium was reached between supply and loss of the algae. However, at a given concentration of algae in the field, temperature may affect IR by affecting the amount of water filtered, i.e. the filtration rate $\left(\mathrm{FR}, \mathrm{ml} \mathrm{h}^{-1}\right)$. If $\mathrm{FR}$ is much lower at $2^{\circ} \mathrm{C}$ than at $12^{\circ} \mathrm{C}$, the higher TAF values at low temperatures may not result in greater biomagnification. In our experiments, FR was only 21 and $32 \%$ lower at $2^{\circ} \mathrm{C}$ than at $12^{\circ} \mathrm{C}$ for the Arctic and temperate mussels, respectively. These drops in filtration rate mean that actual biomagnification at the colder temperature will still be between 1.8- to 5.1-fold higher for the Arctic mussels, and 1.4- to 4.4-fold higher for the temperate mussels.

The relatively modest effect of temperature on filtration rates suggests that mussels from both temperate and Arctic areas can effectively acclimate to temperatures even as low as $2{ }^{\circ} \mathrm{C}$. That mussels can maintain high filtration rates on defined food sources at low temperature when acclimated in the laboratory for more than $14 \mathrm{~d}$ has been well established (Widdows 1973, Bayne \& Newell 1983), and similarly temperature is often found to have little if any influence on filtration rates of Mytilus edulis in the field (Smaal et al. 1997, Cranford \& Hill 1999). However, some modest influence of temperature on filtration rate is suggested by physical constraints imposed by the greater viscosity of colder water (Jørgensen 1990). Ingestion and $\mathrm{C}$ absorption rates remain difficult to predict for field populations of $M$. edulis (Cranford \& Hill 1999), a fact that may account for much of the uncertainty in estimating metal accumulation in the field using a modeling approach. Still, model predictions of metal concentrations at steady-state in bivalve tissue have closely matched independent field measurements for different bivalve species and different waters (Wang et al. 1996, Roditi et al. 2000, Griscom et al. 2002).

Because we were primarily concerned with the assimilation of radiolabel into the pools with the slowest turnover, we have used a rather conservative approach to estimating $\mathrm{AE}$ and $k_{\mathrm{e}}$. Thus, we expect our estimates of $\mathrm{AE}$ to be low by comparison with studies that assume that all radioactivity remaining in the mussels after 3 to $4 \mathrm{~d}$ has been assimilated. Nonetheless, with a few exceptions, our estimates of $\mathrm{AE}$ for $\mathrm{Se}, \mathrm{Am}$ and $\mathrm{Cd}$ were within the range observed in previous studies (Fig. 6). The AE estimates for $\mathrm{Zn}$ and $\mathrm{Ag}$ were relatively low in the $12^{\circ} \mathrm{C}$ experiments, although similar to estimates by Fisher et al. (1996) who used a similar method to calculate AE. Co was assimilated with unusually high efficiency in our experiments. The fact that we did not add cobalamine to the media when radiolabeling the algae may have caused a greater fraction of the ${ }^{57} \mathrm{Co}$ to become associated with cobalamine in our experiments: Co associated with cobalamine in food is assimilated at about twice the efficiency by Mytilus edulis (Fisher et al. 1996). Our estimates of $k_{\mathrm{e}}$ are generally also within the range of previously observed values (Fig. 6). They are high relative to those based on depuration experiments with larger $(3.0$ to $3.5 \mathrm{~cm}$ ) mussels, fed labeled food for extended periods (7 d) and depurated over nearly 1 mo (Wang et al. 1996), but are similar to those measured by Fisher et al. (1996) for M. galloprovicialis in laboratory and field depurations, and by Reinfelder et al. (1997) for $M$. edulis in laboratory depurations.

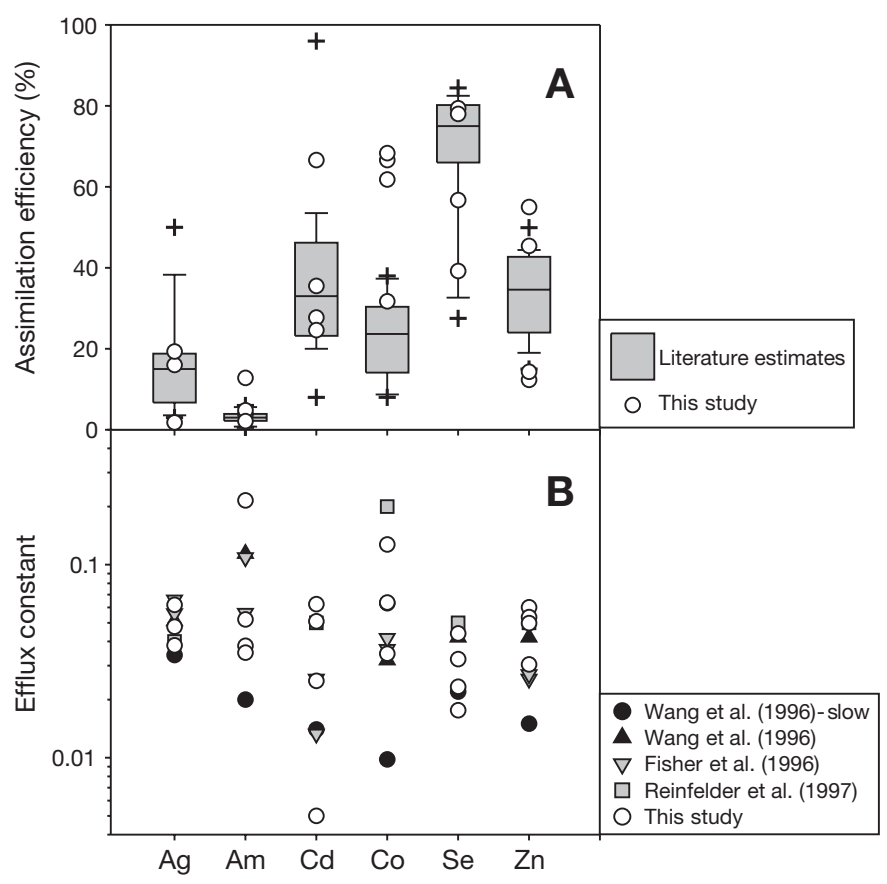

Fig. 6. Mytilus edulis. Comparison of assimilate efficiency $(\mathrm{AE})$ and efflux constant $\left(k_{\mathrm{e}}\right)$ values determined in this study with literature estimates. (A) Sources for AE values are Wang et al. (1995, 1996), Fisher et al. (1996), Wang \& Fisher (1996, 1997) and Reinfelder et al. (1997); measurements include those based on field and laboratory depurations and conditions cover range of feeding rates, food composition, metal concentrations and temperatures; number of observations was 13 for $\mathrm{Ag}$ and Am, 16 for $\mathrm{Co}$ and Se, and 19 for $\mathrm{Zn}$ and $\mathrm{Cd}_{\text {i }}$ central lines denote median values, boxes range between 25th and 75th percentiles, crosses extreme values. (B) $k_{\mathrm{e}}$ values for internal metal pools with slowest turnover rates, except for data from Wang et al. (1996), where turnover rates for both slowest $(\bullet)$ and next slowest $(\mathbf{\Lambda})$ pools are presented 


\section{Effect of population source}

It is possible that, to persist effectively in Arctic environments with a short productive season, Arctic organisms would evolve to maximize the assimilation and retention of food and the elements contained therein. Such adaptation would call into question the applicability of observations on dietary uptake of metals by temperate organisms to Arctic environments. A biological predisposition by Arctic organisms toward accumulation of metal from food would be troubling in light of the elevated supply of some metals and radionuclides in the Arctic. It would also call into question the use of data on temperate organisms in assessing the potential danger of contamination to marine food chains and the native populations that depend on them.

The results of our study suggest that there is little effect of genetic adaptation on bioaccumulation of metals by blue mussels; that is, no appreciable differences were evident between Arctic and temperate populations in metal TAFs. Some significant effects of population origin were seen on $\mathrm{AE}$ for $\mathrm{Co}$ and $\mathrm{Am}$ and on $k_{\mathrm{e}}$ for $\mathrm{Cd}$, but only in the case of $\mathrm{Cd}$ did this translate into a corresponding effect of population origin on the TAF. In that instance, temperate populations of mussels tended to have TAFs for Cd that were on average about 3-fold higher than for Arctic organisms. Otherwise, any variability in AE that was related to population was compensated for by variation in $k_{\mathrm{e}}$, and vice versa. Thus, we cannot support the notion that high $\mathrm{Cd}$ concentrations in some Arctic mussels are attributable to genetic differences resulting from adaptation to life in those environments. Furthermore, at least for Mytilus edulis, our results do nothing to refute the use of results from previous experiments conducted on temperate organisms at low temperatures in assessments of potential contamination or Arctic mussels.

\section{CONCLUSIONS}

Although both assimilation and efflux of metal from the mussels exhibited mixed responses to temperature, we found that temperature, but not population origin, has an influence on the ability of the blue mussel Mytilus edulis to accumulate metal from food. The effect apears to be larger for non-essential metals, such as Am and Ag, than for essential elements, such as Se, $\mathrm{Zn}$ and $\mathrm{Co}$. This is in line with results from previous studies on effects of temperature on turnover of metal obtained through diet by the seastar Asterias forbesi (Hutchins et al. 1996a), but unlike results of experiments with the clam Macoma balthica (Hutchins et al. 1998). The uniformity of the response of TAF to temperature, as opposed to the non-uniform responses of
$\mathrm{AE}$ and $k_{\mathrm{e}}$ may indicate a temperature-dependent regulation of metal retention by the mussels. As a corollary, our results also point out the dangers of assessing the response of only one aspect of metal accumulation (whether assimilation or efflux) to any environmental, phenotypic or genetic variable, since such an approach could obscure the rather simple response of metal biomagnification to temperature. In relation to patterns in nature, the tendency for mussels at $2^{\circ} \mathrm{C}$ to accumulate metals more effectively may help to explain why some Arctic organisms possess relatively high metal concentrations. Our results suggest that it may be fruitful to look for geographic or seasonal patterns in the metal concentrations in the tissues of $M$. edulis that might be related to temperature. They also suggest that understanding the effect of temperature on bioaccumulation of dietary metals will improve predictions of metal concentrations in herbivores as they relate to seasonal and geographic variability. Finally, our results should inform any interpretations of bioinidicator programs that employ $M$. edulis. Since the relationship of bioaccumulation to temperature is probably not linear, more studies that delineate the exact relationship of dietary metal accumulation to temperature are needed.

Acknowledgements. G. S. Stewart and P. K. Lam helped with the experimental setup as well as sampling and maintenance of mussels. Dr. L. Føyn provided mussels from Norway. We thank 4 anonymous reviewers for helpful comments. This research was supported by the US National Science Foundation (OPP-9986069). This is contribution number 1284 of the Marine Sciences Research Center.

\section{LITERATURE CITED}

Bayne BL, Newell RC (1983) Physiological energetics of marine molluscs. In: Aleudin ASM, Wilber KM (eds) The mollusca, Vol 4. Physiology. Academic Press, New York, p 407-515

Boisson F, Hutchins DA, Fowler SW, Fisher NS, Teyssié JL (1997) Influence of temperature on the accumulation and retention of eleven radionuclides by the marine alga Fucus vesiculosus (L.). Mar Pollut Bull 35:313-321

Cranford PJ, Hill PS (1999) Seasonal variation in food utilization by the suspension-feeding bivalve molluscs Mytilus edulis and Placopecten magellanicus. Mar Ecol Prog Ser 190:223-239

de March BGE, de Wit CA, Muir DCG (1998) Persistent organic pollutants. In: AMAP Assessment report: Arctic pollution issues. Arctic monitoring and assessment programme (AMAP), Oslo, p 183-372

Dietz R, Pacyna J, Thomas DJ (1998) Heavy metals. In: AMAP Assessment report: Arctic pollution issues. Arctic monitoring and assessment programme (AMAP), Oslo, p 373-524

Fisher NS (1986) On the reactivity of metals for marine phytoplankton. Limnol Oceanogr 31:443-449

Fisher NS, Reinfelder JR (1995) The trophic transfer of metals in marine systems. In: Tessier A, Turner DR (eds) Metal speciation and bioavailability in aquatic systems. John 
Wiley \& Sons, Chichester, p 363-406

Fisher NS, Teyssié JL, Fowler SW, Wang WX (1996) Accumulation and retention of metals in mussels from food and water: a comparison under field and laboratory conditions. Environ Sci Technol 30:3232-3242

Fisher NS, Fowler SW, Boisson F, Carroll JL, Rissanen K, Salbu B, Sazykina TG, Sjoeblom KL (1999) Radionuclide bioconcentration factors and sediment partition coefficients in Arctic seas subject to contamination from dumped nuclear wastes. Environ Sci Technol 33: 1979-1982

Griscom S B, Fisher NS, Luoma SN (2002) Kinetic modeling of $\mathrm{Ag}, \mathrm{Cd}$ and Co bioaccumulation in the clam Macoma balthica: quantifying dietary and dissolved sources. Mar Ecol Prog Ser 240:127-141

Guillard RRL, Ryther JH (1962) Studies of marine planktonic diatoms. 1. Cyclotella nana Hustedt, and Detonula confervacea (Cleve) Gran. Can J Microbiol 8:229-239

Hansen JC (1998) Pollution and human health. In: AMAP Assessment report: Arctic pollution issues. Arctic monitoring and assessment programme (AMAP), Oslo, p 775-844

Hutchins DA, Stupakoff I, Fisher NS (1996a) Temperature effects on accumulation and retention of radionuclides in the sea star, Asterias forbesi: implications for contaminated northern waters. Mar Biol 125:701-706

Hutchins DA, Teyssié JL, Boisson F, Fowler SW, Fisher NS (1996b) Temperature effects on uptake and retention of contaminant radionuclides and trace metals by the brittle star Ophiothrix fragilis. Mar Environ Res 41:363-378

Hutchins DA, Stupakoff I, Hook S, Luoma SN, Fisher NS (1998) Effects of Arctic temperatures on distribution and retention of the nuclear waste radionuclides ${ }^{241} \mathrm{Am},{ }^{57} \mathrm{Co}$, and ${ }^{137} \mathrm{Cs}$ in the bioindicator bivalve Macoma balthica. Mar Environ Res 45:17-28

Jørgensen CB (1990) Bivalve filter feeding: hydrodynamics, bioenergetics, physiology and ecology. Olsen \& Olsen, Fredensborg

Lee JG, Morel FMM (1995) Replacement of zinc by cadmium in marine phytoplankton. Mar Ecol Prog Ser 127:305-309

Nieboer E, Richardson DH (1980) The replacement of the nondescript term 'heavy metals' by a biological and chemically significant classification of metal ions. Environ Pollut Ser B 1:3-26

Nolan C, Fowler SW, Teyssié JL (1992) Cobalt speciation and bioavailability in marine organisms. Mar Ecol Prog Ser 88: 105-116

Phillips DJH (1980) Quantitative aquatic biological indicators. Applied Science Publishers, London

Reinfelder JR, Fisher NS (1991) The assimilation of elements ingested by marine copepods. Science 251:794-796

Reinfelder JR, Wang WX, Luoma SN, Fisher NS (1997) Assimilation efficiencies and turnover rates of trace elements in marine bivalves: a comparison of oysters, clams, and mussels. Mar Biol 129:443-452

Reinfelder JR, Fisher NS, Luoma SN, Nichols JW, Wang WX (1998) Trace element trophic transfer in aquatic organisms: a critique of the kinetic model approach. Sci Total Environ 219:117-135

Riginos, C, Sukhdeo, K, Cunningham CW (2002) Evidence for selection at multiple allozyme loci across a mussel hybrid zone. Mol Biol Evol 19:347-351

Roditi HA, Fisher NS, Sañudo-Wilhelmy SA (2000) Field testing a metal bioaccumulation model for zebra mussels. Environ Sci Technol 34:2817-2825

Slemr F, Langer E (1992) Increase in global atmospheric concentrations of mercury inferred from measurements over the Atlantic Ocean. Nature 355:434-437

Smaal AC, Vonck A, Bakker M (1997) Seasonal variation in physiological energetics of Mytilus edulis and Cerastoderma edule of different size classes. J Mar Biol Assoc UK 77:817-838

Strand P (1998) Radioactivity. In: AMAP Assessment report: Arctic pollution issues. Arctic monitoring and assessment programme (AMAP), Oslo, p 525-620

Templeton W, Harrison F, Knezovich J, Fisher N, Layton D (1997) Bioconcentration of radionuclides in marine foodweb organisms. In: Layton D, Edson R, Varela M, Napier B (eds) Radionuclides in the Arctic seas from the former Soviet Union: potential health and ecological risks. Office of Naval Research, Washington, DC, p 4-1-4-12

Wallace W, Lopez G (1996) Relationship between subcellular cadmium distribution in prey and cadmium trophic transfer to a predator. Estuaries 19:923-930

Wang WX, Fisher NS (1996) Assimilation of trace elements and carbon by the mussel Mytilus edulis: effects of food composition. Limnol Oceanogr 41:197-207

Wang WX, Fisher NS (1997) Modeling the influence of body size on trace element accumulation in the mussel Mytilus edulis. Mar Ecol Prog Ser 161:103-115

Wang WX, Fisher NS (1999) Assimilation efficiencies of chemical contaminants in aquatic invertebrates: a synthesis. Environ Toxicol Chem 18:2034-2045

Wang WX, Fisher NS, Luoma SN (1995) Assimilation of trace elements ingested by the mussel Mytilus edulis: effects of algal food abundance. Mar Ecol Prog Ser 129:165-176

Wang WX, Fisher NS, Luoma SN (1996) Kinetic determinations of trace element bioaccumulation in the mussel Mytilus edulis. Mar Ecol Prog Ser 140:91-113

Widdows J (1973) Effect of temperature and food on heart beat, ventilation rate and oxygen-uptake of Mytilus edulis. Mar Biol 20:269-276

Widdows J, Fieth P, Worrall CM (1979) Relationship between seston, available food and feeding activity in the common mussel Mytilus edulis. Mar Biol 50:195-207

Submitted: June 4, 2004; Accepted: September 9, 2004

Proofs received from author(s): March 8, 2005
Editorial responsibility: Otto Kinne (Editor-in-Chief), Oldendorf/Luhe, Germany 